\title{
Approach to the cascade retrospective study of heterozygous familial hypercholesterolemia: A statistical tool to better understand family dependence and the index case
}

Maria Christiane Valéria Braga Braile-Sternieri, Eliana Migliorini Mustafa, Victor Rodrigues Ribeiro Ferreira, Bethina Canaroli Sbardellini, Sofia Braile Sabino, Giovanni Braile Sternieri, Luiza Braile Verdi', Idiberto José Zotarelli Filho* and Domingo Marcolino Braile

Domingo Braile Institute of Sao Jose do Rio Preto (SP), Rua Luiz Vaz de Camoes, 3111 - Vila Redentora, 15015-750, Brazil

\section{Introduction}

Familial hypercholesterolemia (FH) is an autosomal dominant genetic condition (LDL-C), in which apolipoprotein B or pro-protein is converted to subtilisin/kexin [1]. The diagnosis depends on factors such as family history and clinical presentation, genetic tests and severe elevations in plasma cholesterol levels [2]. Heterozygous $\mathrm{HF}$ ( $\mathrm{HeFH})$ is more common, occurring in approximately one in 500 people in the world. Homozygous FH, on the other hand, is apparently rare, occurring in approximately one in 1 million individuals [3].

\section{Objective}

To analyze by means of the multivariate analysis (Dendogram) the correlation of the $\mathrm{HeFH}$ of a family with 14 members by means of a retrospective study in genealogical cascade to elucidate the behavior of this pathology along the family descent.

\section{Methods}

The present study adopted the male patient AA as the Index Case (reference) of the entire study. Thus, 13 relatives, including his wife (non-FH), were correlated by a new statistical approach (Dendogram) to understand the genetic inheritance of $\mathrm{HeFH}$ by the degree of similarity of total cholesterol.

\section{Results}

The multivariate analysis allowed the qualitative and quantitative understanding of the family relationship of heterozygous hypercholesterolemia in terms of total cholesterol. The Index Case did not genetically influence their daughters and granddaughter, with $0.00 \%(\mathrm{p}>0.05)$ (Figure 1).

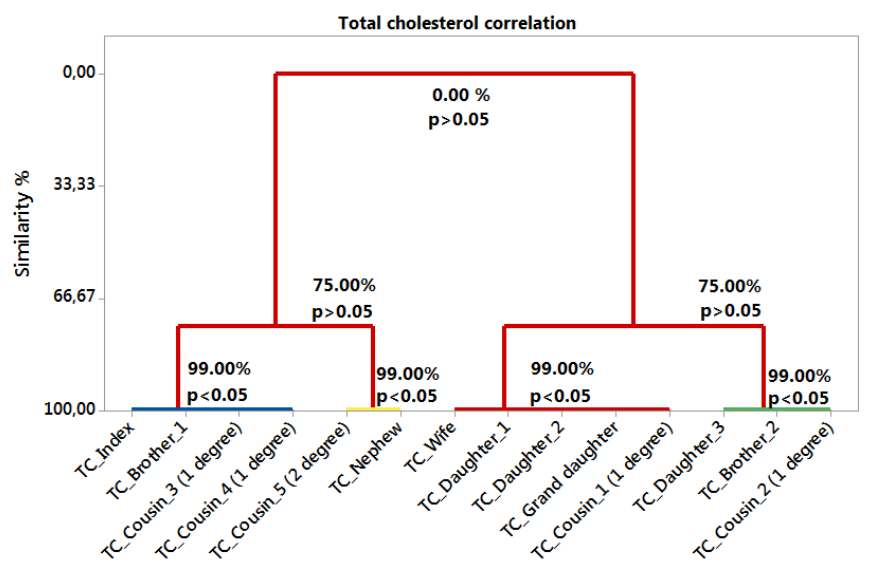

Figure 1. Multivariate analysis of the family relationship of heterozygous hypercholesterolemia in terms of total cholesterol. It was adopted $p>0.05$ as statistically different (CI 95.0\%).

\section{Conclusion}

The multivariate analysis (dendrogram) proved to be an important and more didactic tool to determine the degree of genetic dependence of $\mathrm{FH}$ on relatives with the Index Case.

\section{References}

1. Onorato A, Sturm AC (2016) Heterozygous Familial Hypercholesterolemia Circulation 133: e587-589. [Crossref]

2. Cheng S, Wu Y, Wen W, An M, Gao Y, et al. (2019) Independent Severe Cases of Heterozygous Familial Hypercholesterolemia Caused by the W483X and Novel W483G Mutations in the Low-Density Lipoprotein Receptor Gene That Were Clinically Diagnosed as Homozygous Cases. Genet Test Mol Biomarkers 23: 401-408. [Crossref]

3. Rodríguez-Jiménez C, Pernía O, Mostaza J, Rodríguez-Antolín C, de Dios García-Díaz J, et al. (2019) Functional analysis of new variants at the Low Density Lipoprotein Receptor associated with familial hypercholesterolemia. Hum Mutat [Crossref]
Copyright: (C2019 Braile-Sternieri MCVB. This is an open-access article distributed under the terms of the Creative Commons Attribution License, which permits unrestricted use, distribution, and reproduction in any medium, provided the original author and source are credited.
*Correspondence to: Idiberto José Zotarelli Filho, Domingo Braile Institute of São José do Rio Preto (SP), Rua Luiz Vaz de Camoes, 3111 - Vila Redentora, 15015-750, Brazil, Tel: 5517-981666732; E-mail: m.zotarelli@gmail.com

Received: June 06, 2019; Accepted: June 20, 2019; Published: June 25, 2019 